\title{
Monoamine Oxidase Activity in Membrane Structures of Rat Liver Cell
}

Monoamine oxidase activity in homogenates of liver, brain and some other organs is localized mainly in mitochondrial fraction ${ }^{1}$ and is tightly bound with mitochondrial membranes ${ }^{2}$. On fractionation of mitochondrial membranes, the monoamine oxidase activity in some cases ${ }^{3,4}$ was found in a fraction termed 'external mitochondrial membranes'. Monoamine oxidase (EC 1.4.3.4) has therefore been considered as a 'marker enzyme' for external mitochondrial membranes 4, 5 .

In homogenates of thyroid gland ${ }^{6}$, heart musele ${ }^{7}$ and of some other organs and tissues, a considerable part of monoamine oxidase activity has been localized in microsomes. However, direct evaluation, under comparable experimental conditions, of monoamine oxidase activity in various membrane structures of a cell has not been carried out.

It was one purpose of the present work to compare the values of specific monoamine oxidase activity (measured by a highly sensitive colorimetric method based on following the rate of oxidation of p-nitrophenylethylamine ${ }^{8,9}$ ) in various membrane structures of rat liver cell.

Preparations of mitochondrial membranes ${ }^{10}$, cytoplasmic membranes ${ }^{11}$, nuclei ${ }^{12}$ and nuclear membranes (envelopes) ${ }^{13}$, as well as those of membraneous structures of ergastoplasmic reticulum ${ }^{14}$, were suspended in $0.2 \mathrm{M}$ potassium phosphate buffer ( $\mathrm{pH}$ 7.4). Content of protein has been measured as described by Lowny et al. ${ }^{15}$ using crystalline beef serum albumin as a standard.

The Figure shows that in mitochondrial membranes (which contain more than $70 \%$ of the total monoamine oxidase activity of rat liver homogenate ${ }^{1}$ ) specific monoamine oxidase activity calculated per mg of protein is considerably lower, as compared with the monoamine oxidase activity in cytoplasmic membranes or, especially, in nuclear membranes (envelopes). In some experimental hepatomas, this enzymatic activity is almost absent ${ }^{16}$.

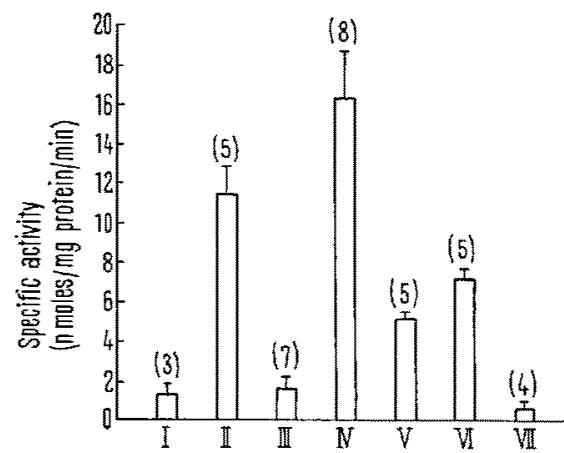

Specific monoamine oxidase activity in membrane structures of rat liver cell. Substrate p-nitrophenylethylamine. $\mathrm{HCL}^{8}$. Composition of samples and experimental conditions as described previously ${ }^{9}$. Mean values 7 standard deviation are presented. Number of experiments in parentheses. I, starting homogenate; II, cytoplasmic membranes; III, nuclei; IV, nuclear membranes (envelops); V, mitom chondria; VI, mitochondrial membranes; VII, membrancous structures of ergastoplasmic reticulum.
Monoamine oxidase activity may therefore not be considered as a characteristic property of mitochondrial membranes.

Biological significance of monoamine oxidase activity in membrane structures of cell is at the present time unknown. A possible role for these enzymes is suggested by the previously published data ${ }^{17}$ on participation in regulation of activity of some structure - bound enzymes of tissue respiration of deaminated products of biogenic monoamines metabolism. Formation of these products is prevented by specific powerful monoamine oxidase inhibitors ${ }^{17}$.

Вывод. Моноаминоксидазная ақтивность присуща не только митохондриальным мембранам, но и некоторым другим мембранным структурам клетки.

V. Z. GORKIN

Institute of Biological and Medical Chemistry, Academy of Medical Sciences of the USSR, Moscow G-117 (USSR), 13 July 1970.

1 V. Z. GoRkin, Pharmac. Rev. 18, 115 (1966).

2 I. V. Verrovkina, V. Z. Gorkin, V. M. Mityushin and I. E. ElpINer, Biophysics (Moscow) 9,503 (1964).

${ }^{3}$ C. Schnatruan, V. G. Erwin and J. W. Greenawalt, J. Cell Biol. 32, 719 (1967).

"C. Schinaiman and J. W. Greenawalt, J. Cell Biol. 38,158 (1968).

${ }^{5}$ K. F. Tipton, Biochim. biophys. Acta 135, 910 (1967).

${ }^{B}$ A. G. Fischer, A. R. Schulz and L. Oliner, Biochim. biophys. Acta 159,460 (1968).

7J. de Champlain, R. A. Mueller and J. Axelrod, J. Pharmac. exp. Ther. 166,339 (1969).

${ }^{8}$ E. A. Zeller, H. R. Buerki and T. Ishimaru, Fedn Proc. 21, 271 (1962).

${ }^{9}$ V. Z. Gorkin, Zh. I. Akopyan, E. N. Goncharenko and Yu. B. Kudryashov, Vop. med. Kbim. 14, 538 (1968).

10 W. R. Frisell, M. V. Patwardhan and C. G. Mackenzie, J. biol. Chem. 240, 1829 (1965). Preparations of mitochondrial membranes were kindly presented by Dr. I. V. VERYOVKINA.

11 P. Emmerot and C. J. Bos, Biochim. biophys. Acta 58, 374 (1962). Preparations of cytoplasmic membranes were kindly presented by Dr. S. YA. Davydova.

12 A. Di Grolamo, E. C. Henshaw and H. H. Hiatt, J, molec. Biol. $8,479(1964)$. Purified preparations of nuclei were kindly presented by Prof. I. B. Zbarsky and Dr. S. N. Kuzmina.

13 I. B. Zrarsky, K. A, Perevostchikova and L. N. DelektorSkAYA, Dokl. Akad. Nauk SSSR 177, 445 (1967). Preparations on nuclear membranes (envelopes) were kindly presented by Prof. I. B. ZBARsKY and Dr. S. N. KUZMINA.

14 A. 1. Archakov, V. M. Devichensky, I. I. Karuzina, N. N. Ivkov, T. A. Alexandrova, P. P. Doronin and M. L. Sorokina, Biokhimiya 33, 479 (1968). - A. I. Archakov, L. F. Panchenko, I. I. Karvzina and T. A. Alexandrova, Biokhimiya 34, 604 (1969). Preparations of the structural elements of ergastoplasmic rcticulum were kindly presented by Dr. A. I. Archakov.

15 O. H. LOWRY, N. J. Rosebrovgh, A. L. FARR and R. F. RANDALl, J. biol. Chem. 193, 265 (1951).

16 V. Z. Gorkin, S. N. KuZmina and I. B. ZBarsky, Dokl. Acad. Nauk SSSR 197, 472 (1970).

17 V. Z. Gorkin and R. S. Krivchenkova, Vop. med. Khim. 13, $428(1967)$.

\section{Enzymatic Phosphorylation of Proteins of Rat Liver Chromatin by $\left(\gamma-{ }^{32} P\right)$ ATP in vitro}

The role played by chromosomal proteins in the control of gene activity is one of the main points of current interest. A characteristic of these proteins is the existence of several chemical groups on the amino acid side chains of the molecule, such as methyl, acetate and phosphate, groups which modify the net charge and perhaps the interaction of the protein with the nucleic acids of the chromatin $^{\mathbf{1}}$. It has been postulated and evidence has 